\title{
Journal of Urban History
}

http://juh.sagepub.com/

Urban Forms and Civic Space in Nineteenth- to Early Twentieth-Century Bangkok and Rangoon

Elizabeth Howard Moore and Navanath Osiri

Journal of Urban History 2014 40: 158 originally published online 27 September 2013

DOI: $10.1177 / 0096144213504381$

The online version of this article can be found at:

http://juh.sagepub.com/content/40/1/158

\author{
Published by:

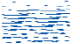 \\ http://www.sagepublications.com \\ On behalf of: \\ Urban History Association
}

Additional services and information for Journal of Urban History can be found at:

Email Alerts: http://juh.sagepub.com/cgi/alerts

Subscriptions: http://juh.sagepub.com/subscriptions

Reprints: http://www.sagepub.com/journalsReprints.nav

Permissions: http://www.sagepub.com/journalsPermissions.nav

>> Version of Record - Nov 26, 2013

OnlineFirst Version of Record - Sep 27, 2013

What is This? 


\title{
Urban Forms and Civic Space in Nineteenth- to Early Twentieth- Century Bangkok and Rangoon
}

\author{
Elizabeth Howard Moore' and Navanath Osiri ${ }^{2}$
}

\begin{abstract}
Buddhist spaces in Bangkok and Rangoon both had long common traditions prior to nineteenthand early twentieth-century colonial incursions. Top-down central city planning with European designs transformed both cities. While Siamese kings personally initiated civic change that began to widen economic and social interaction of different classes, British models segregated European, Burmese, Indian, and Chinese populations to exacerbate social differences. In addition, the Siamese rulers maintained and enhanced civic spaces of religious compounds while the British occupied the Shwedagon pagoda for military purposes and created spacious gardens for their own use. The article underlines the disparity in the provision of urban forms in central city planning between the royal vision of nation-building developed by King Chulalongkorn and his successor King Vajiravudh and the new capital of Rangoon laid out by colonial engineers where the traditional ritual spaces became the staging ground for nationalist movements. In both cities, urban forms and civic spaces were essential in legitimizing political authority. The article demonstrates the manner in which spatial and visual systems colored the production of civic space to initiate social integration in Bangkok and preamble disintegration in colonial Rangoon.
\end{abstract}

\section{Keywords}

colonial, civic space, Rangoon, Bangkok

\section{Introduction: Bangkok and Rangoon}

Prior to royal and colonial interventions in the late nineteenth and early twentieth century, Buddhist places in Bangkok and Rangoon had long functioned as civic spaces. With the introduction of European culture, new designs and areas transformed the layout and urban culture of these cities. This article contrasts the tangible and intangible modifications to highlight the differences between the royal renovation of Bangkok and the colonial structuring of Rangoon and the manner in which these forms regulated the ability of civic space to initiate social change.

\footnotetext{
'Department of History of Art and Archaeology, School of Oriental and African Studies, London, United Kingdom
} 2Department of Landscape Architecture, Chulalongkorn University, Bangkok

\section{Corresponding Author:}

Elizabeth Howard Moore, Department of History of Art and Archaeology, School of Oriental and African Studies, Thornhaugh Street, London WCIHOXG, United Kingdom.

Email: em4@soas.ac.uk 


\section{The Remodeling of Bangkok}

Over a period of some fifty years, from 1870 to 1925 , the royal programme of urban beautification in Bangkok transformed the city spatially and socially. A very personalized royal

prerogative remodeled religious, royal, and secular areas to introduce novel ideas. After traveling through the capitals of Europe, King Chulalongkorn (r. 1868-1910) laid out a grand avenue with an equestrian statue of himself at the end of the vista, an icon that has remained a focal point for the population of Bangkok until now. In tandem with spatial changes such as this was a series of "winter fairs" sponsored by the king in the palace grounds where the personal participation of the king animated the display of new European goods and entertainments. The winter fairs gave unprecedented access to novel goods while previously out-of-bounds royal areas were opened for the many different ethnic groups and social classes of the expanding city. With the individual involvement and tastes of the Chakri rulers, European modes and artists were commandeered, superimposing an imperial vision onto the physical social fabric of the city.

King Chulalongkorn and King Vajiravudh (r. 1910-1925) remodeled and built new palaces and temples. Broad avenues were laid across the city and in the space of Phra Lan and the equestrian statue, a uniquely royal civic space in the heart of the city was open to all. Likewise, the royal winter fairs and festivals were sparked by the participation of the king and his close circles that brought an excitement and novel class liberality to these events. Nonelite civic space was for the first time introduced adjacent to elite festival grounds. While this may seem a token introduction, it was a major initiative in a country where prostration in the royal presence had been the norm. The changing spaces actively stimulated new types and levels of consumption that in tandem a novel idea of social openness set the stage for a sense of community and nation.

\section{The Construction of Rangoon}

Rangoon experienced a very different and divisive transformation, administered rather than personally driven as was the case in Bangkok. The city remained small until British occupation after the Second Anglo-Burmese War (1850-1852), but with colonial rule, the small town was soon overlaid with a new urban plan. When Lord Dalhousie visited Rangoon in late 1852, he noted that "the place will certainly grow in importance as a port." New cities had been laid out in Sittwe in northwest Arakan and Moulmein in the south facing the Gulf of Martaban after the First Anglo-Burmese war of A.D. 1824-1826 but apart from a river-front grid in the south part of the city, the new city at Rangoon more closely resembled Calcutta, a "classic example of colonialbased city development." 2 The bulk of the population, Indian and Chinese, lived in the closely laid web of the "work premises" areas near the river, with other areas allocated for residential and "open spaces" to the north around the colonial-fortified Shwedagon pagoda hill. ${ }^{3}$ The chessboard pattern was seen by many as the obvious choice: models ranged from the rebuilding of London after the Great Fire of 1666 to the usual plan of "old colonial towns."

The Report of the Suburban Development Committee, Rangoon (1917) and the Report of the Departmental Committee on Town Planning (1917) declared Rangoon to be "without question a very well designed and beautiful city." Broad scenic areas situated well north of the downtown river-side grid following the fashionable nineteenth-century British picturesque aesthetic, a carefully designed naturalism embodying the ruling elite and prominent bourgeoisie wealth and social prominence. ${ }^{5}$ Additional gardens such as the Cantonment and Dalhousie Gardens were laid out in the area surrounding the Shwedagon pagoda hill situated between the downtown and northern residential areas. Although spatially integrated with existing urban precincts, the new civic spaces gave little positive impetus for any integration of local and colonial cultural life in Rangoon. 


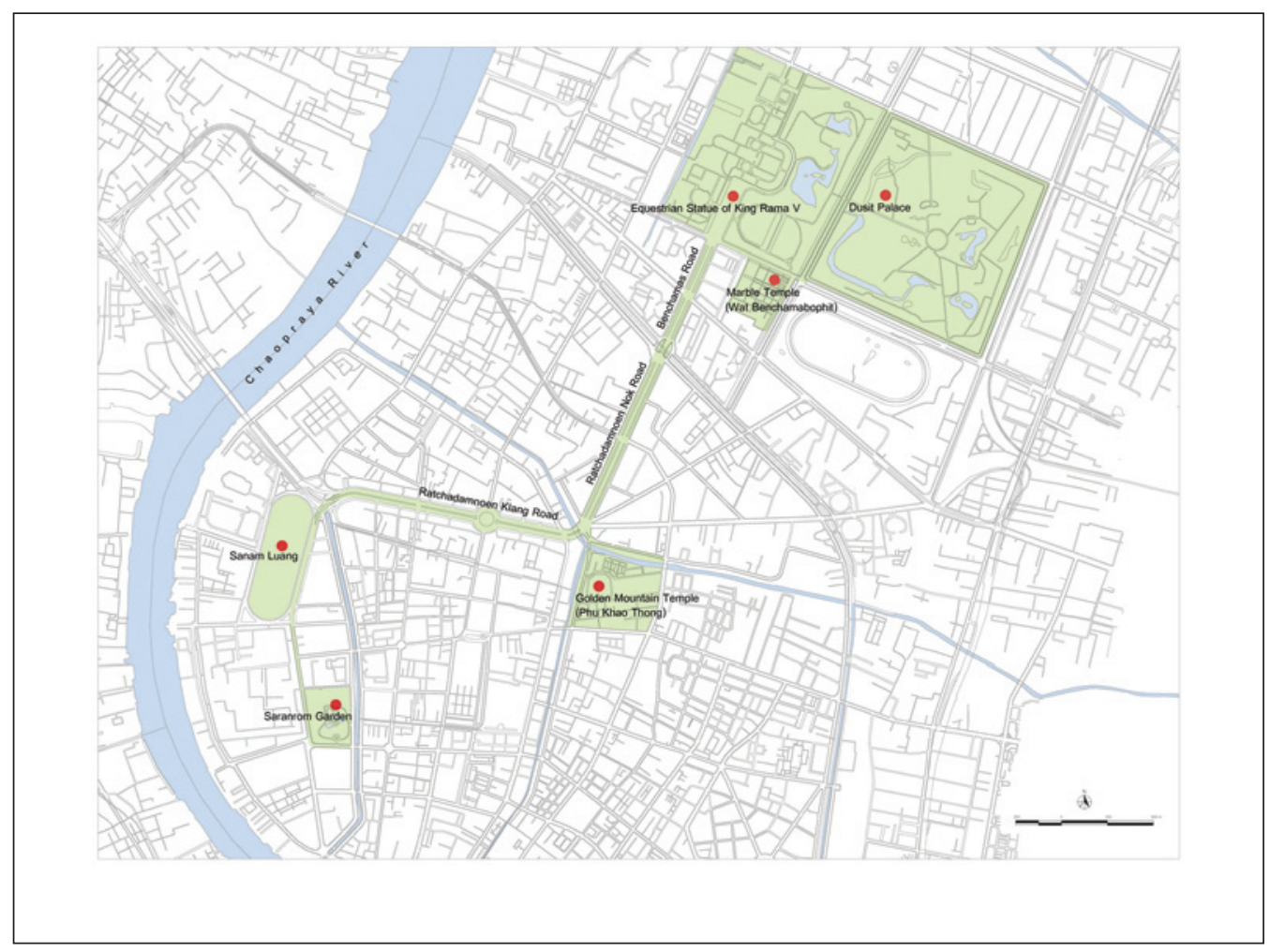

Figure I. Bangkok's civic spaces in the early twentieth century. Source: N. Osiri.

\section{Bangkok's Civic Spaces}

A network of canals and Buddhist temples epitomized the urban landscape of early Bangkok even before the capital moved from Thonburi on the opposite bank of the Chao Phraya River to Bangkok in 1782 (Figure 1). The royal center was established along the river where the Grand Palace and royal temples were set within a tall fortified wall. Only aristocrats resided in the compound, with graded settlements differentiated not only by "class and status, but by ethno-geography as well." 6 From the second half of the nineteenth century to early twentieth century, the shape of the capital changed significantly as the "fort and port" city became both the "capital of a new nation-state and the centre of a booming rice and teak export trade." 7 Streets replaced canals as main thoroughfares while the role of temples as places for social gathering lessened. Royal decrees created new open areas not only for visual effect but as part of a wider reimaging of the monarchy where civic spaces were a functional part of the city. ${ }^{8}$

The emergence of a new urban landscape in Bangkok began in the reign of King Mongkut (r. 1851-1868) after the 1855 signing of the Bowring Treaty. Europeans flocked to the capital for commercial opportunities, while the European material progress attracted the Siamese court. The first Western-styled street, Charoen Krung, for example, was initially built in 1862 to facilitate European recreational and social activities. Charoen Krung was soon followed by the construction of two more streets, Bamrung Muang and Fuang Nakhon, bringing a different type of urban space to Bangkok. 


\section{King Chulalongkorn's Royal Travels}

The royal travels from 1871 to 1907 to European empires and Asian colonial cities sparked major changes in the administration and life of Thailand. The king examined the intricacies of modern political administration and the new technology of this era and had a keen interest in the cultural and leisure activities that had arisen in tandem with industrialization and a growing middle class in Europe. The king also began to explore civic entertainment with the royal adoption of Westernstyle amusements such as theatrical performances later seen in "temple fairs" held during the reign of King Chulalongkorn. Before going to Europe, Chulalongkorn visited Singapore and Java in 1871, familiarizing himself with standards introduced in these cities by British and Dutch colonial rule. The close royal attention included landscaping and, upon his return from Java, King Chulalongkorn commissioned Saranrom Royal Garden just east of the royal palace in Bangkok. This was the first Western-styled garden in Siam, with a club and theater for elite clientele. One of the king's advisors, Chao Phraya Phanupong suggested to the king that the design of Asian colonial capitals epitomized that of European imperial capitals and counseled the monarch to replace a planned visit to Europe with an 1872 journey to British India and Burma. ${ }^{9}$

Like his earlier journey to Singapore and Indonesia, the king's travels to India prompted study of colonial policy and public works. It was, however, the royal trips to Europe in 1897 and 1907 that fully sparked the royal imagination and set in motion significant changes to the urban and social landscapes of Bangkok. The Siamese monarch sought out royal precedents in London, Paris, Berlin, Brussels, Copenhagen, St. Petersburg, and Vienna. The king took note of the monuments and gardens, uniform buildings, and particularly the tree-lined avenues and grand vistas that were a regular part of European stately planning. Avenues and huge open spaces that in particular provided cultural spaces where monarchy could be celebrated were soon echoed in a series of new constructions in Bangkok. The royal temple of Benjamabophit (1898), the grand axis of the esplanade of Rachadamnoen Avenue (1899), the equestrian statue of Phra Lan (1898), and the siting and decorative elements of Dusit Palace Park (1898) were all part of the royal vision to transform Bangkok into an "imperial" city (Figure 2).

\section{European Models}

King Chulalongkorn chose imperial design to epitomize his royal supremacy not to civilize his status, an intentional placing of Siam alongside the monarchs of Europe. The superimposition of new urban design in prominent features such as Rachadamnoen Avenue, the royal equestrian statue, and the massive arch described below tangibly echoed this stance. New civic spaces spatially segregated from existing urban areas were not reserved for the royal family but strategically used within a wider program national identity and social integration. As the construction of Dusit Palace expanded the urban area of Bangkok some four kilometers inland from the river, the processional Rachadamnoen Avenue was designed to connect the royal ground of Sanam Luang with the new palace compound. The equestrian statue of King Chulalongkorn at the end of Rachadamnoen Avenue was set in the middle of the royal plaza or Phra Lan with the Ananta Samakhom Throne Hall as the backdrop. As Prince Damrong Rajanubhab noted, however, the statue was not only a symbol of imperial authority but also intended as an emblem of social harmony with the royal plaza and the throne hall seen by many to embody the king's supreme sovereignty in modern Siam. ${ }^{10}$ The statue was consecrated to commemorate the king's fortieth anniversary on the throne, with the ceremony drawing a huge populace to attend the celebrations and entertainment. Notably, this space has retained its popularity as an urban theater for all classes from the time it was unveiled to the present (Figure 3).

Other European models inspired additional new urban elements for Bangkok, including a monumental arch, tower clock, and fountains. King Chulalongkorn had initially planned a massive arch across the full sixteen-meter width of Benjamas or Phra Lan Road to serve as a civic 


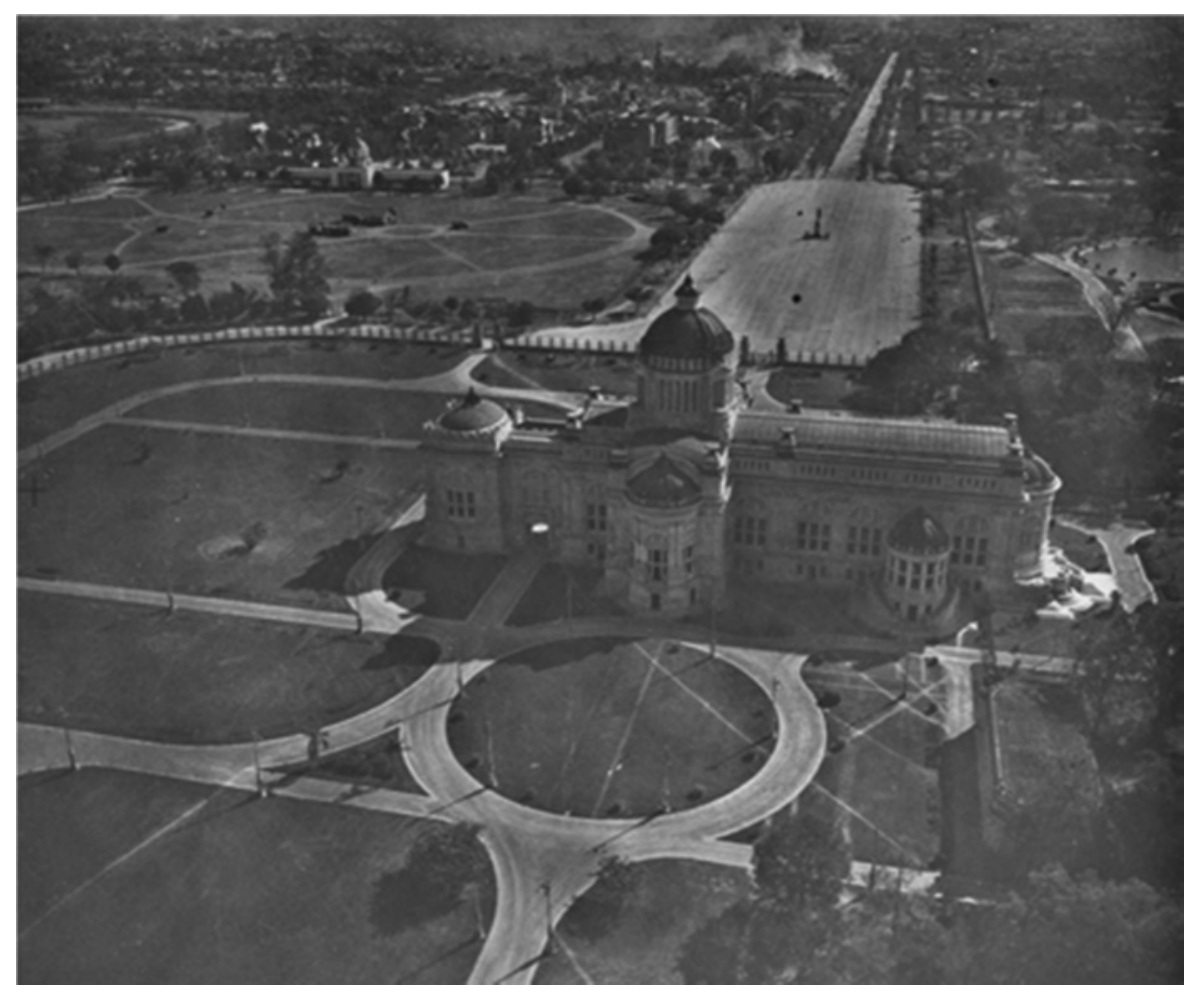

Figure 2. Aerial view of Phra Lan and Ananta Samakhom throne hall.

Source: Williams-Hunt Collection, courtesy School of Oriental and African Studies, London.

monument and gateway to Dusit Palace. Supervised by Prince Narisaranuvativongse, the monumental design included three spans providing road access with colonnades stretching to both sides. A tower clock was also proposed as a landmark to be erected at Phan Phiphop Lila Bridge near Sanam Luang. In addition, the royal gazette notes that King Chulalongkorn planned to incorporate quadruple fountains and a patterned garden at the base of his equestrian statue. An Italian craftsman was hired as an officer of the Public Work Department to mold the fountain bowls. At the end of the day, the arch, the tower clock, and the fountains were never implemented because of financial constraints, but the vision and complexity of the projected planning reflect the scale and energy of the monarch to underscore the grand vista of Rachadamnoen Avenue and to infuse "modern" Bangkok with civic monuments (Figure 4).

Importantly, as the particulars of each of these projects highlights, Bangkok's new urban improvements were not simply an emulation of Europe but a selective appropriation harmonizing the monarchy's taste with an existing physical environment. The landscape of Rachadamnoen Avenue was, according to Prince Chulachakrabongse, modeled after the Mall in London and the Champs Elysees in Paris. ${ }^{11}$ Spatially, however, the plan of the new royal esplanade is closer to the new urban scheme of London where the idea of a grand processional avenue and memorial to Queen Victoria was proposed in 1896. The tree-lined Mall linked Admiralty Arch to Buckingham Palace with the statue of Queen Victoria set in front. Unlike the later Rachadamnoen and Phra Lan, the Mall was originally off bounds to commoners, built for royal recreation where the kings played the seventeenth-century game of pall-mall. ${ }^{12}$

Another royal adaptation of European models was trees as King Chulalongkorn noted that most of the European streets were flanked with rows of trees. The royal objective was not merely 


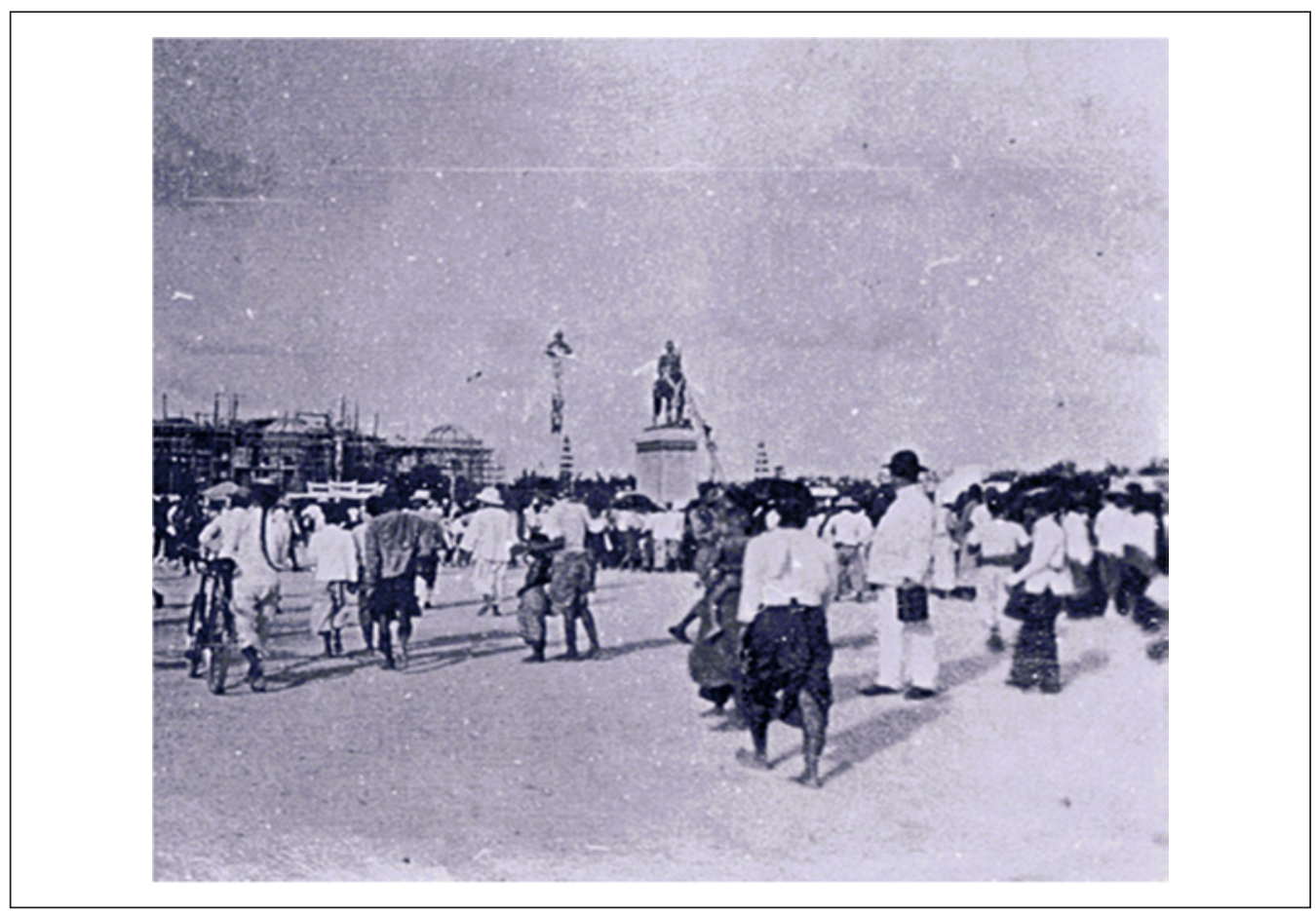

Figure 3. Celebrations in 1908 for the equestrian statue.

Source: National Archives of Thailand.

aesthetic, but provided shaded sidewalks, with the trees including tamarind, Indian almond, and Indian rosewood. In 1902, four hundred tamarind trees delivered from Monthon Thesaphiban Nakhon Chaisi ${ }^{13}$ were planted along the periphery of the royal ground of Sanam Luang. In between the two rows of tamarind trees, a two-meter walkway was laid out that transformed the former royal ceremonial ground into a large urban recreational space for the urban populace (Figure 5).

A series of urban improvements brought a new meaning to the capital. King Chulalongkorn chose imperial design for Bangkok to represent his royal supremacy with the aim of placing Siam in equal position to imperial nations. ${ }^{14}$ The superimposition of European aesthetics in urban design reflected royal resistance to colonialism. New civic spaces including parks, avenues, and squares were spatially segregated from local urban areas. But they were not privileged spaces for the elite; in fact, they were strategically used as a tool to cultivate national identity and promote social integration.

\section{Festivals and Fairs}

King Chulalongkorn sought out a range of cultural spaces during his visits, going to the palaces, museums, exhibitions, avenues, opera houses, and royal gardens all over Europe. The records of the Royal Secretariat of King Chulalongkorn's first trip to Europe, for example, cite visits to Tivoli Garden in Denmark and Bois de Boulogne in France. ${ }^{15}$ As the king saw, these served as new recreational and entertainment places for middle and upper classes. Upon his return to Bangkok, he sponsored a new series of fairs and festivals that introduced novel civic spaces and recreational culture where elite and common classes could jointly celebrate. Festivals and spectacles became a royal tool to proclaim physical and social links with the populace and introduce Western culture. Royal open spaces inspired by European Imperial design, together with the 


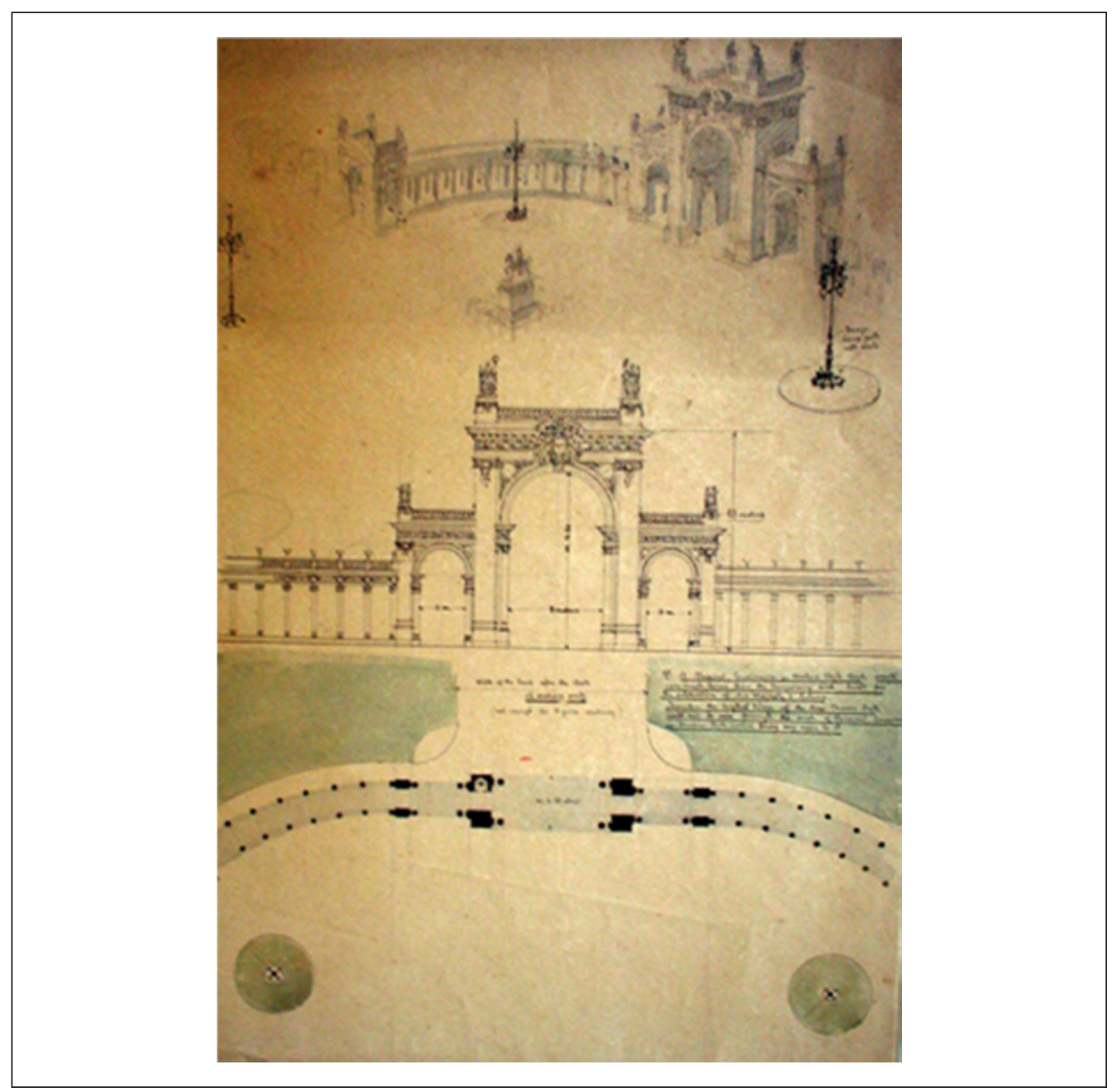

Figure 4. Drawing of the royal arch to span Phra Lan Road.

Source: Personal Archive of Professor Elena Tamagno, Turin, Italy. Courtesy of Assistant Professor Dr. Rachaporn Choochuey.

earlier Saranrom Royal Garden (1874), were, by the reign of King Vajiravudh opened for festivals to all classes.

\section{Sanam Luang and Golden Mount}

One of the many goals of King Chulalongkorn and his successor King Vajiravudh was to instill their particular vision of global modernity into local taste and behavior. Through fairs and festivals where they brought their personal bias for European culture, they began to turn royal spaces into civic spaces. The social repercussions were varied, with for example the new types of entertainment staged for the royal winter fairs creating a new genre of recreational culture. The novel elements were not only for royal and elite but deliberately made accessible to middle and lower classes. At the same time, the winter fairs allowed certain forms of popular culture and plays usually performed for ordinary citizens to be enjoyed by upper classes. Although royally managed and lasting only for the duration of the winter fair, the royal fairs and festivals 


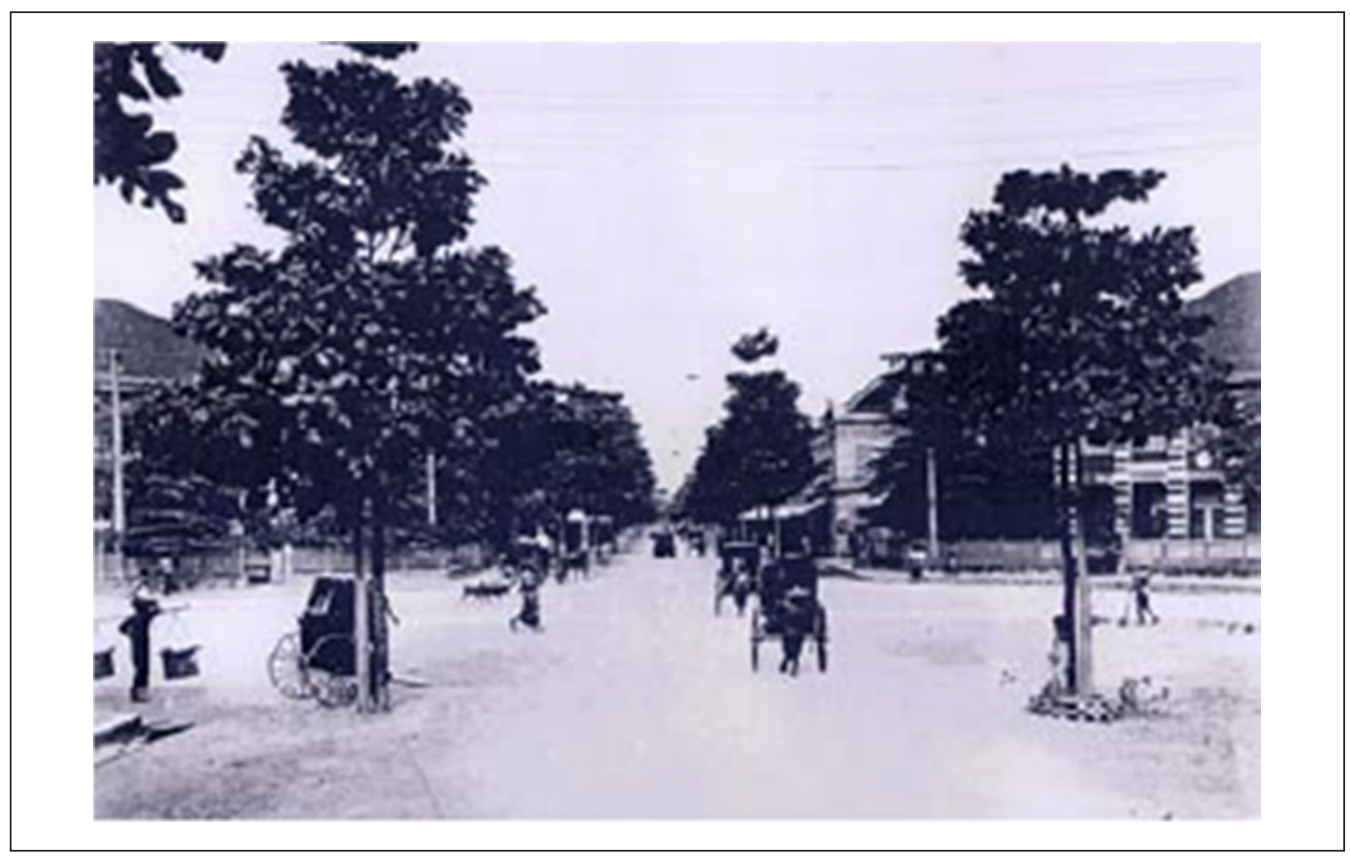

Figure 5. Trees lining Charoen Krung Street.

Source: The National Archives of Thailand.

organized in royal spaces introduced a new style of social integration. Even before staging the winter fairs, King Chulalongkorn began to open up other spaces and festivals to all classes of the urban populace.

In the late eighteenth century early Rattanakosin period, the large open area of Sanam Luang was swampy with tall grass, only occasionally used for royal cremations. The large open area was not intended to be a civic space, with the participation of common people restricted to the entertainments and performances that commemorated royal cremations. During the reign of King Chulalongkorn, however, Sanam Luang became a civic arena for both elite and lower classes. Traditional kite-flying was often seen in tandem with new Western leisure activities such as golfing, cycling, and horseback riding. In addition, King Chulalongkorn also introduced international exhibition-type fairs. For example, the 1882 centennial celebrations of Bangkok that corresponded to the king's fiftieth birthday were open to all.

Temple fairs, normally held in the grounds of the temple, had long been a traditional form of local entertainment in Siam. The temple grounds in this sense were traditional civic spaces where social activities and religious ceremonies were held. Such occasions included performances of traditional music and plays. In 1890, King Chulalongkorn sponsored the temple fair at the Golden Mount Temple to celebrate the inauguration of a stupa containing relics of the Buddha. The royal sponsorship encouraged a plethora of performances and goods stalls. There was classical Siamese music, Chinese puppets, plays, quoits (the throwing of rings to land on a spike), and the alternating voices of antiphonal singing. Stalls sold the popular betel and areca quids for chewing and religious amulets while others exhibited various freaks and oddities. Public participation included various minority ethnic groups and people from all classes of society. ${ }^{16}$

\section{Wat Benjamabophit, Dusit, and Chitralada "Winter Fairs"}

The king's patronage of the Golden Mount festival was seven years before his first journey to Europe. Upon his return, King Chulalongkorn continued this traditional patronage but also 


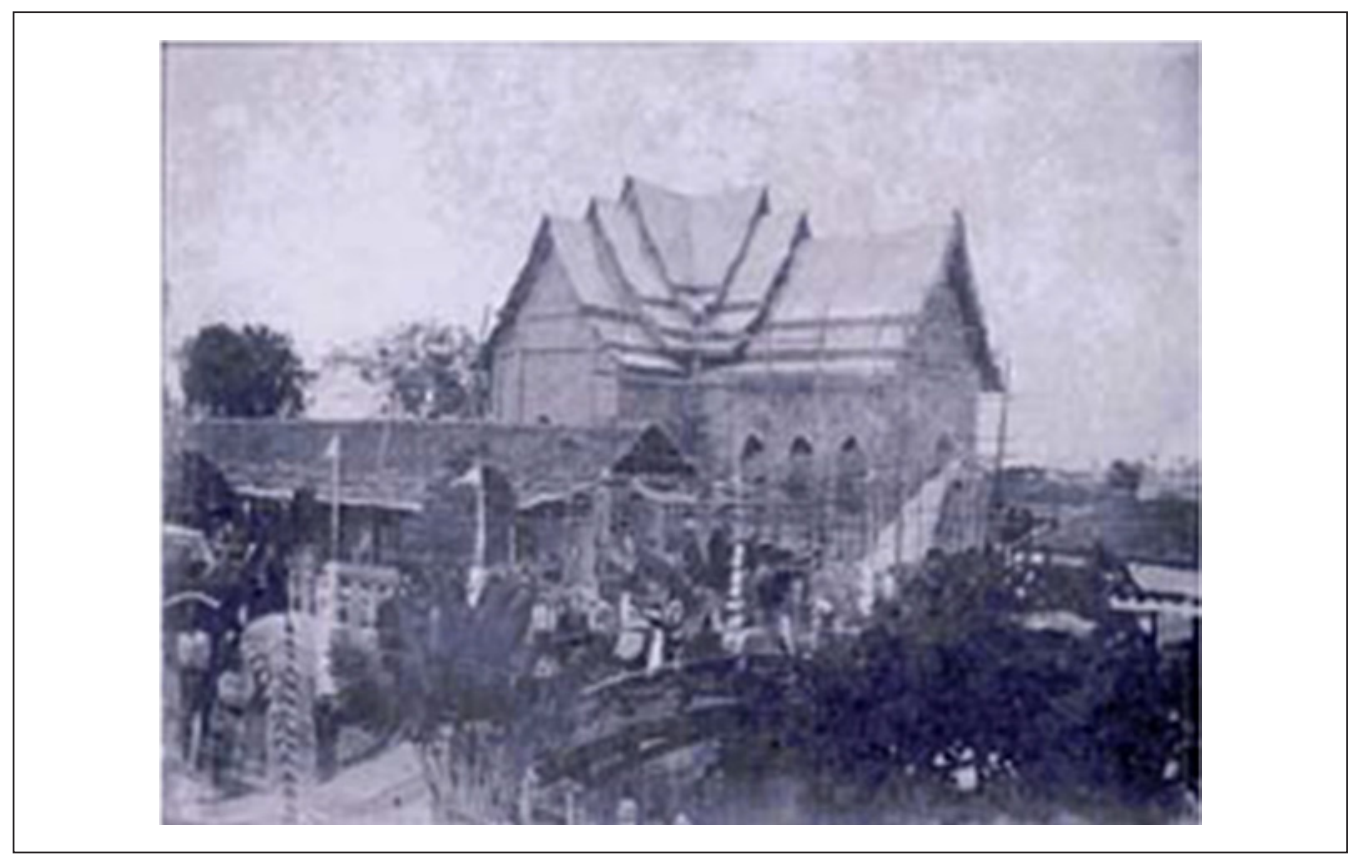

Figure 6. The 190I fair at Wat Benjamabophit.

Source: The National Archives of Thailand.

instituted a host of new events in temple and garden venues. Many of these were the first introduction to European social genres and foreign goods for citizenry from various ethnic groups and social classes. For example, just two years after his first trip to Europe, in 1899, he rebuilt Wat Benjamabophit as a royal monastery. King Chulalongkorn did not change social traditions abruptly but used the temple grounds, a traditional civic space, as a starting point to introduce European forms and goods to the urban society of Bangkok. The main structure, the ordination hall, was faced with Italian marble and surrounded by a lawn, an unusual feature for Thai monasteries (Figure 6).

In 1901, the King held his first temple fair at the remodeled wat to raise funds for temple construction and inaugurate the presiding image of the Buddha. Three types of booths were permitted, with ownership by royal, elite, and common people. The booths for common people were called sampheng, a name probably derived from the old Chinese trading and commercial area in Bangkok. They were erected outside the walled compound of the temple proper and staged popular local festivals and sold inexpensive produce and goods. As such, the temple fair sampheng quickly became popular with lower and middle classes for their prices and games of chance. In contrast, the royal and elite booths were set on the lawn adjacent to the ordination hall. They included a brass band, plays, phonograph, and gramophone sets and a photographic competition. The king even set up his own personal photographic stall, where he took portraits, often with himself included with customers. The December 9-15, 1905, Wat Benjamabophit fair was open to foreigners, with customers solicited in an English advertisement that urged all to "Come and see ... The Royal Theatre of Siamese Legends under the superintendence of the Chow Phya Devesrs from 8pm daily." 17 The fairs held in Sanam Luang and the royal temple's precinct reflected the royal preamble to Western culture by deploying traditional civic spaces as a starting point to educate the people.

In the next reign, King Vajiravudh extended the festival venue into the royal spaces of Dusit Palace and then royal gardens. He officially proclaimed the festival as a "winter fair" and arranged that all donations from the fair went to the Royal Navy. Stalls in the area of Dusit Palace Park 
were preserved for royal elites, with exhibits including Western plays, a large oval labyrinth and an enormous ship's model. The sampheng were located outside the royal spaces in the area to the west of Wat Benjamabophit. While many of the stall models were adapted from European models, Princess Poonpisamai made a special point of recording in her diary how the stalls and plays in sampheng were like those at traditional fairs at the Golden Mount temple festival. ${ }^{18}$ Although commoners and elite stalls were spatially separate, Prince Chula Chulachakrabongse proclaimed that the Dusit winter fair was the most eagerly awaited event of the year. He described it as a place for informal leisure, a pleasurable gathering where all classes of people could dress up and intermingle. ${ }^{19}$

In 1918, the now-famous winter fair was held in the park of Chitralada Palace, a residence of King Vajiravudh in the Dusit Palace precinct. This time the fair revenues were donated to Vajiravudh College. Besides entertainment, the fair aimed to bring in new examples of Western art and science. Four years later, the King moved the annual winter fair to Saranrom Royal Garden near the old Palace. Designed by a British advisor Henry Alabaster during the reign of King Chulalongkorn, the garden was modeled after Kew Royal Botanic Garden in England. Intended for royal leisure, the Saranrom grounds included a Western-style club called Thavipanya Samoson and a royal theater. According to one observer, the winter fair, held annually in December-January inside the garden, was reserved primarily for upper classes. Royal and elite stalls, flanking both sides of garden walkways, displayed a variety of goods and activities, such as jewelry, blue and white porcelain, Italian marble sculptures, and Ford and Fiat automobiles. There was a ballroom with European dancing accompanied by violins and a royal dining pavilion. ${ }^{20}$ The Sampheng, commoners' stalls, were, however, located outside the garden adjacent to the fences along Sanamchai Road (Figure 7).

In their sponsorship of the grand winter fairs and festivals, King Chulalongkorn and King Vajiravudh brought, albeit temporary, civic space into the palace grounds. This royal custom was maintained until 1925 when King Vajiravudh donated his crown property for the construction of the first public park in Siam. Located in the southeast of Bangkok, the park was designed in a picturesque style with a lake, canals, islands, meandering pathways, a Chinese clock tower, and Greek-style building. Intended to boost the declining economy after World War I, the king created the park as a civic space, first for national exhibitions and later for recreational purposes. Throughout these developments, the tangible changes to the city were used to initiate intangible social change, a very different integration and vision of the relationship of the physical and social in the making and use of the city than that of Rangoon.

\section{British Rangoon}

New civic spaces were also created in Rangoon in the late nineteenth and early twentieth century as the British transformed the small fishing town of Dagon into the colonial capital (Figures 8 and 9). Burma was Britain's last frontier in "Greater India," bringing a sense of periphery that is significant in understanding the liberty taken in appropriating the Shwedagon pagoda as a military fortress and transforming its glebe lands into a large cantonment to house troops and to provide garden areas reserved for colonial servants. Rangoon's transformation into a colonial capital was especially noticeable as, unlike other cities such as Phnom Penh that altered from a royal to a colonial capital, Rangoon was never the heart of the royal domain. Also, unlike cities such as French Vientiane, where a royal esplanade was modeled after Paris, the British brought little of London's civic space to colonial Rangoon, concentrating instead on the construction of a profitable port city spatially segregated in three main areas: the congested multiethnic "downtown" street grid, the residential areas of Europeans and a few Burmese and Chinese elite surrounded by open spaces, and, at the center of the city, the Shwedagon pagoda surrounded by large tracts of British cantonment and garden lands. 


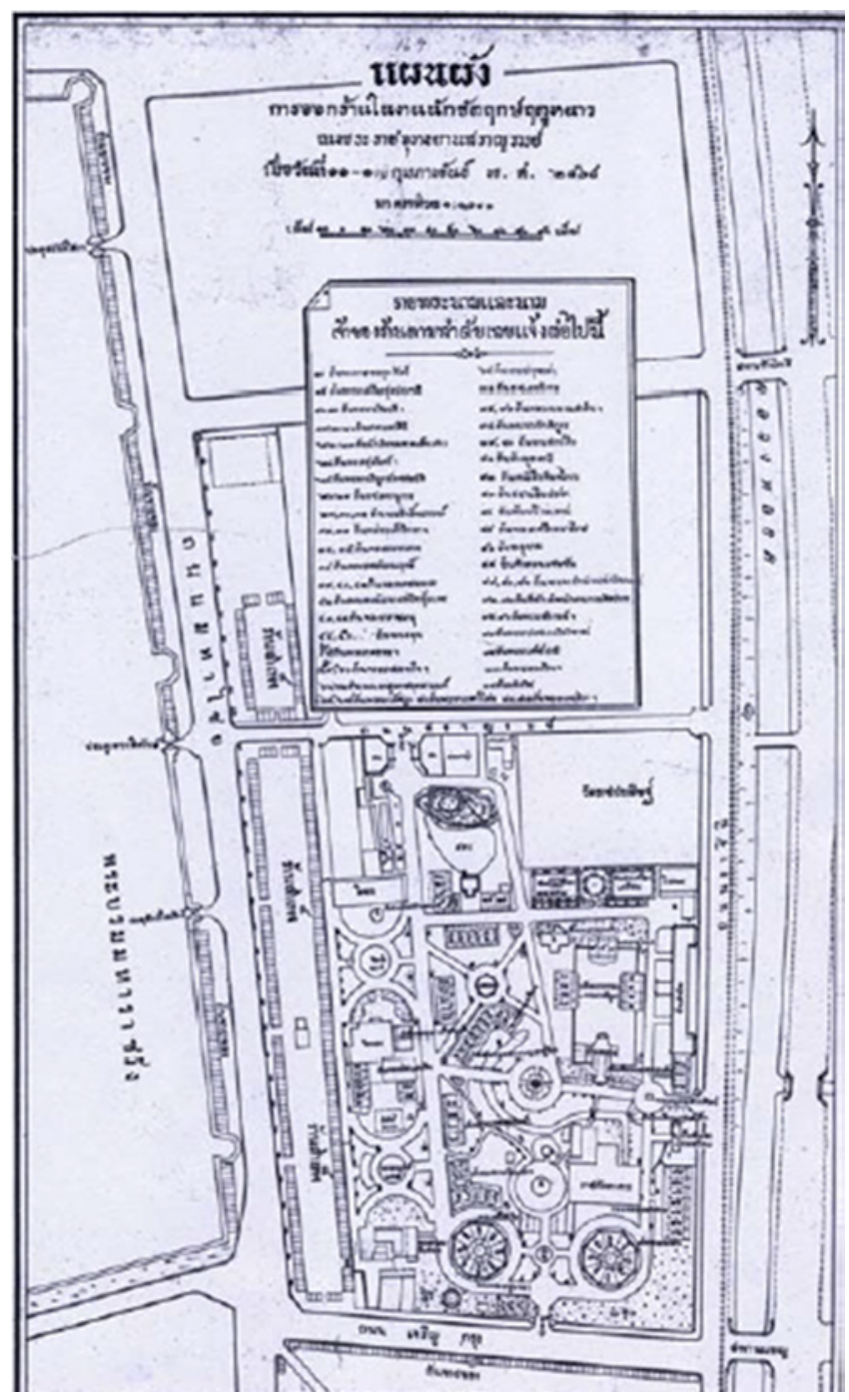

Figure 7. Plan of the winter fair at Saranrom Garden. Source: The National Archives of Thailand.

\section{Urban Growth and Civic Space}

Rangoon's civic spaces were administered by the British but segregated by the diverse interests of British civil servants and officers sent to Rangoon from India, the immigration of a sizeable number of Indian civil servants able to carry out new administrative needs in English and Indian and Chinese workers to ensure commercial success. Ethnic distinctions were intensified by the growing population, the city expanding from 98,745 to 293,316 between 1872 and 1911. In 1872, the Burmese, Indian, Chinese, and European population of Rangoon was $67 \%$, $25 \%, 3 \%$, and $2 \%$ respectively but by 1911 , the Burmese had dropped to $31 \%$ while Indian citizens were 58\%. ${ }^{21}$ Construction of commercial buildings in downtown Rangoon rose in tandem with a regular road system and drainage. ${ }^{22}$ Drainage canals were covered with wide sidewalks that particularly in the rainy season created new areas for traders and socializing. ${ }^{23}$ These "inadvertent" civic spaces became active places of social interchange for the Burmese, Indian, 


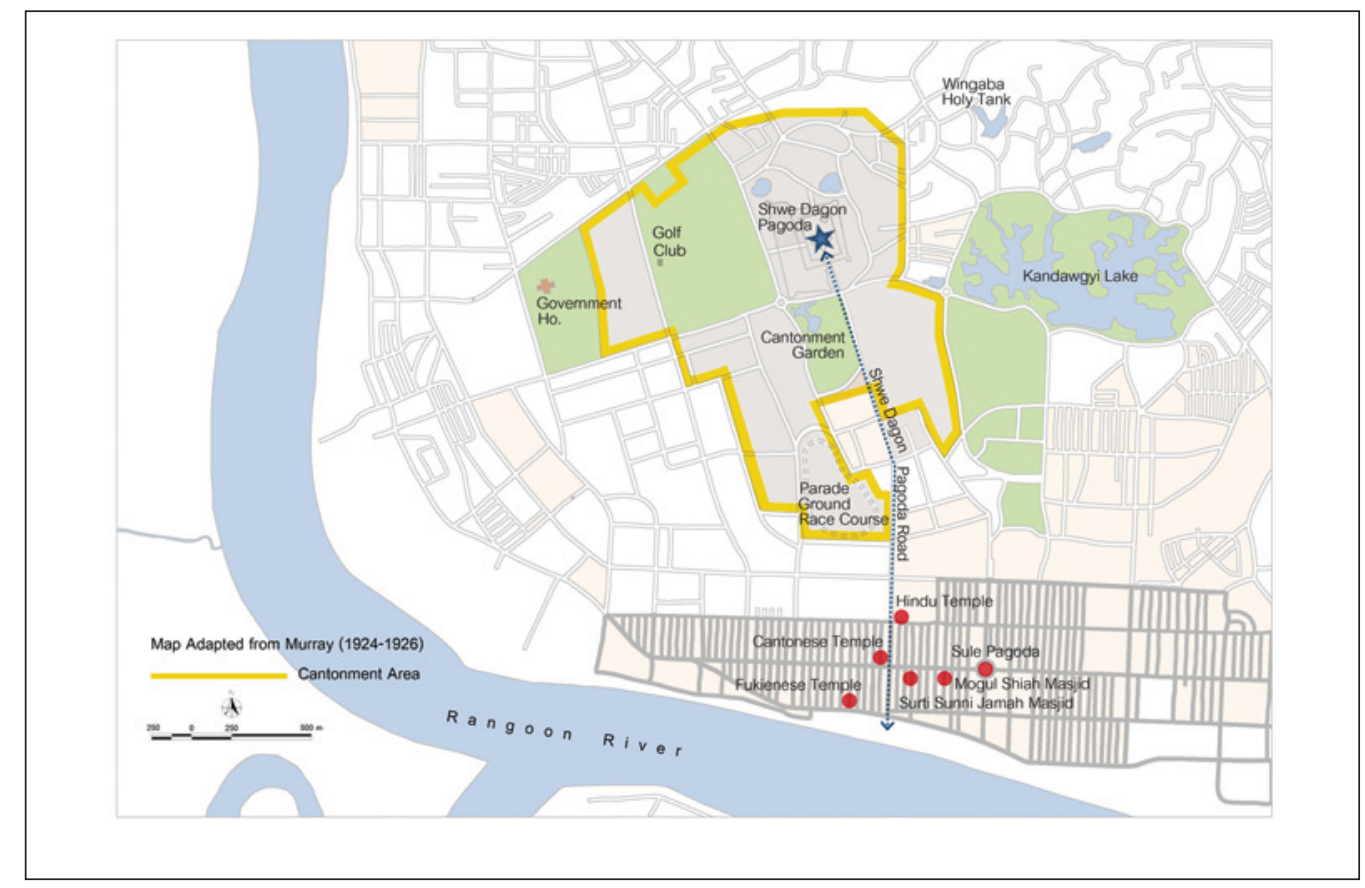

Figure 8. Rangoon map.

Source: After Murray (1924).

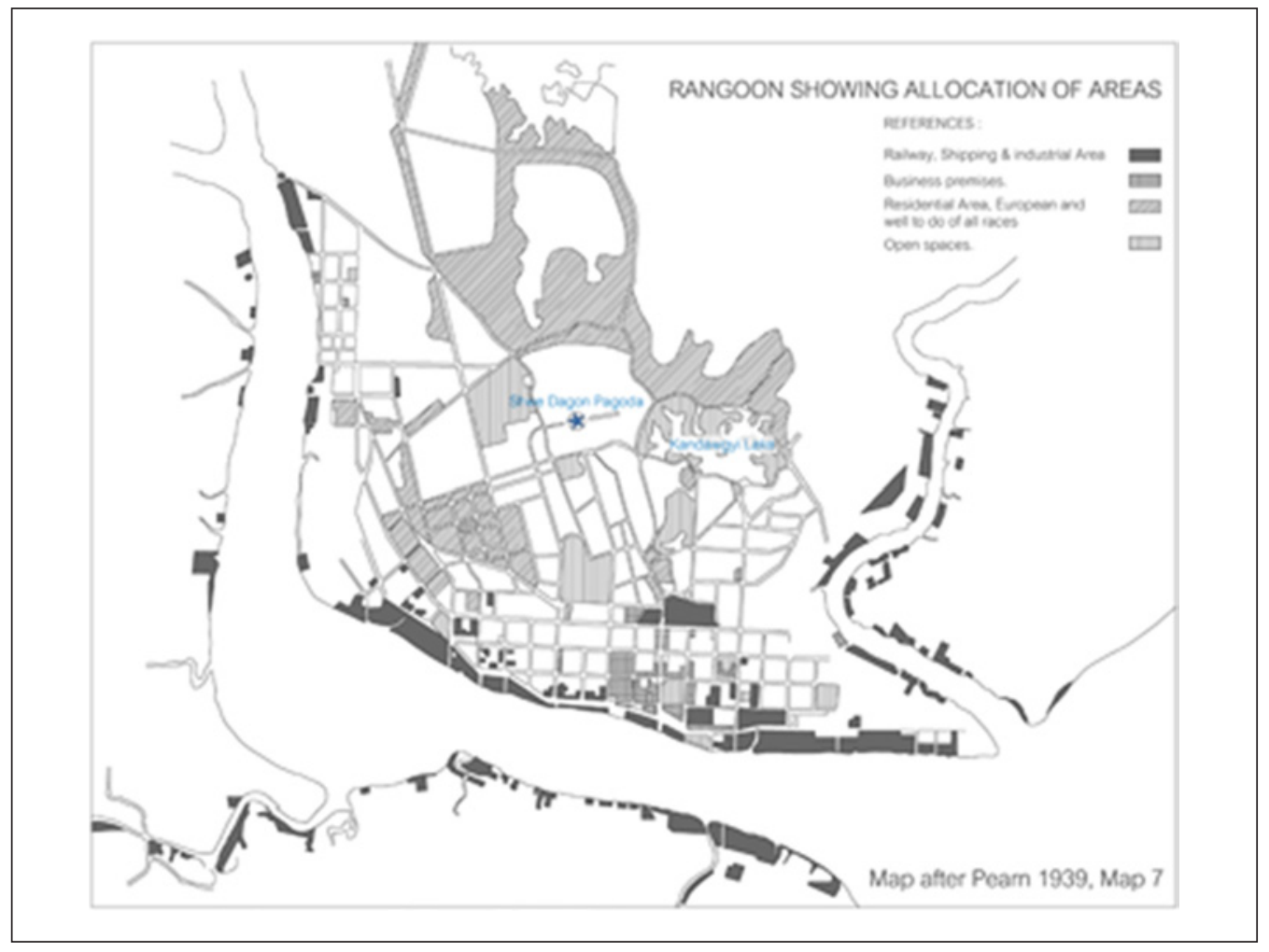

Figure 9. Rangoon map of "Designated Areas."

Source: After Pearn (1939), Map 7. 


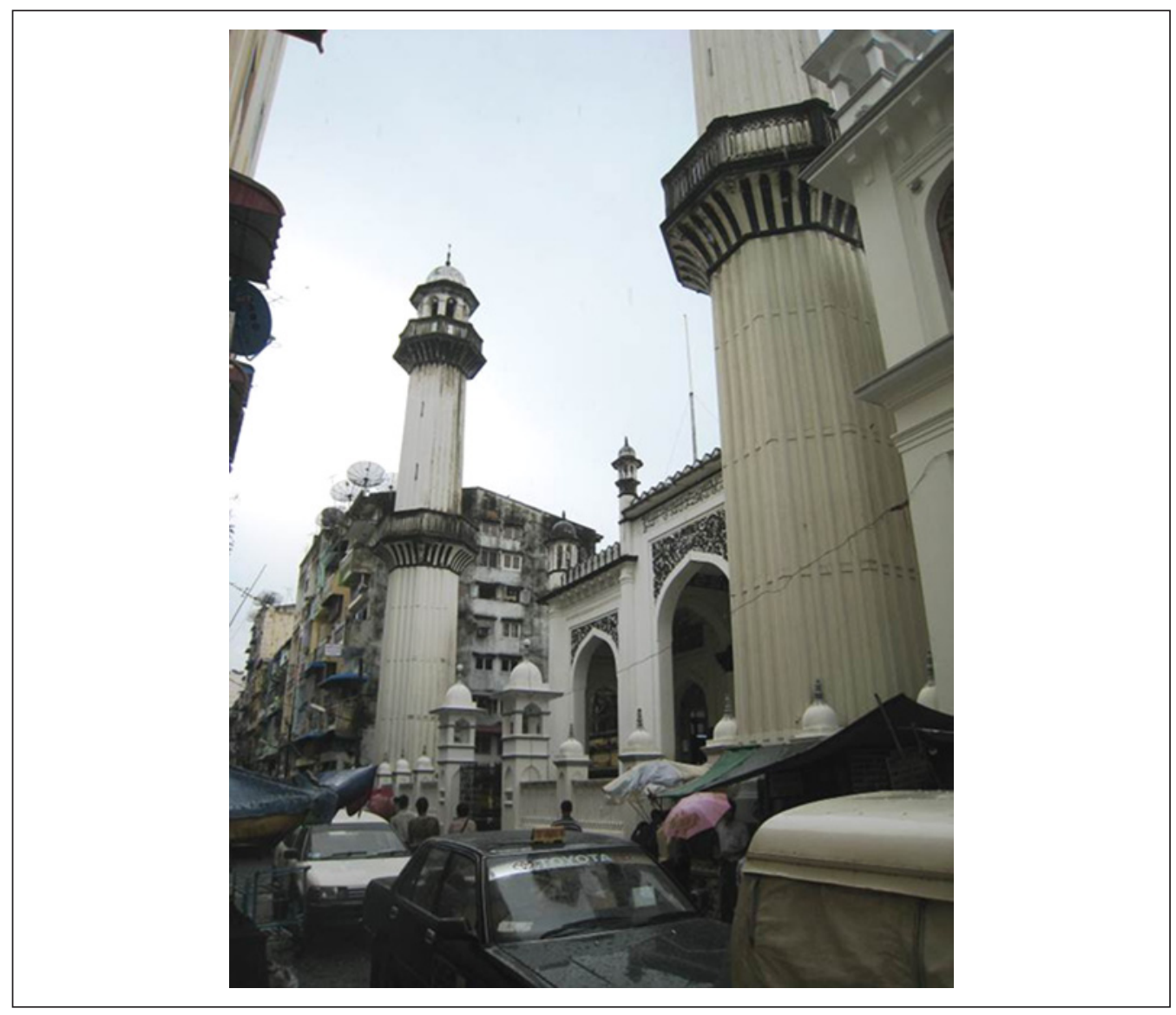

Figure 10. Rangoon, 30th Street mogul Shia Jamay Masjid today. Source: E. H. Moore.

and Chinese during the rapid expansion of the colonial economy and changing demographics of the city.

A large percentage of the Indian and Chinese population lived in the downtown areas, each neighborhood marked by distinctive diaspora religious architecture, the heart of the neighborhood civic life. ${ }^{24}$ Some of the earliest were Muslim: the 1826 Surti (Sooratee) Sunni Jamah Masjid (Great Mogul Street Mosque) was built by immigrants from the western part of India and the 1854 Mogul Shiah Masjid by Indo-Persian merchant families. The Cantonese community supported the Kuanyin Temple (1868) while the Fukienese built the Hokkien Kheng Hock Keong temple in $1861 .{ }^{25}$ Each group had local festivals, sometimes intersecting with those of the British but, for the most part, in contrast to the control accorded to the king in transforming Bangkok; although colonial prerogatives shaped the urban forms, the civic space and social life of each ethnic and religious group remained separate (Figure 10). Many of the pagodas in areas just south of the Shwedagon extended further down to the Sule pagoda and the downtown area. In the gridlike layout of streets close to the waterfront, other non-Buddhist religious structures mixed with godowns, shops, houses, and sidewalk markets to provide social space for much of the large Indian population of Muslims and Hindus as well as Chinese and other minority groups noted above. 


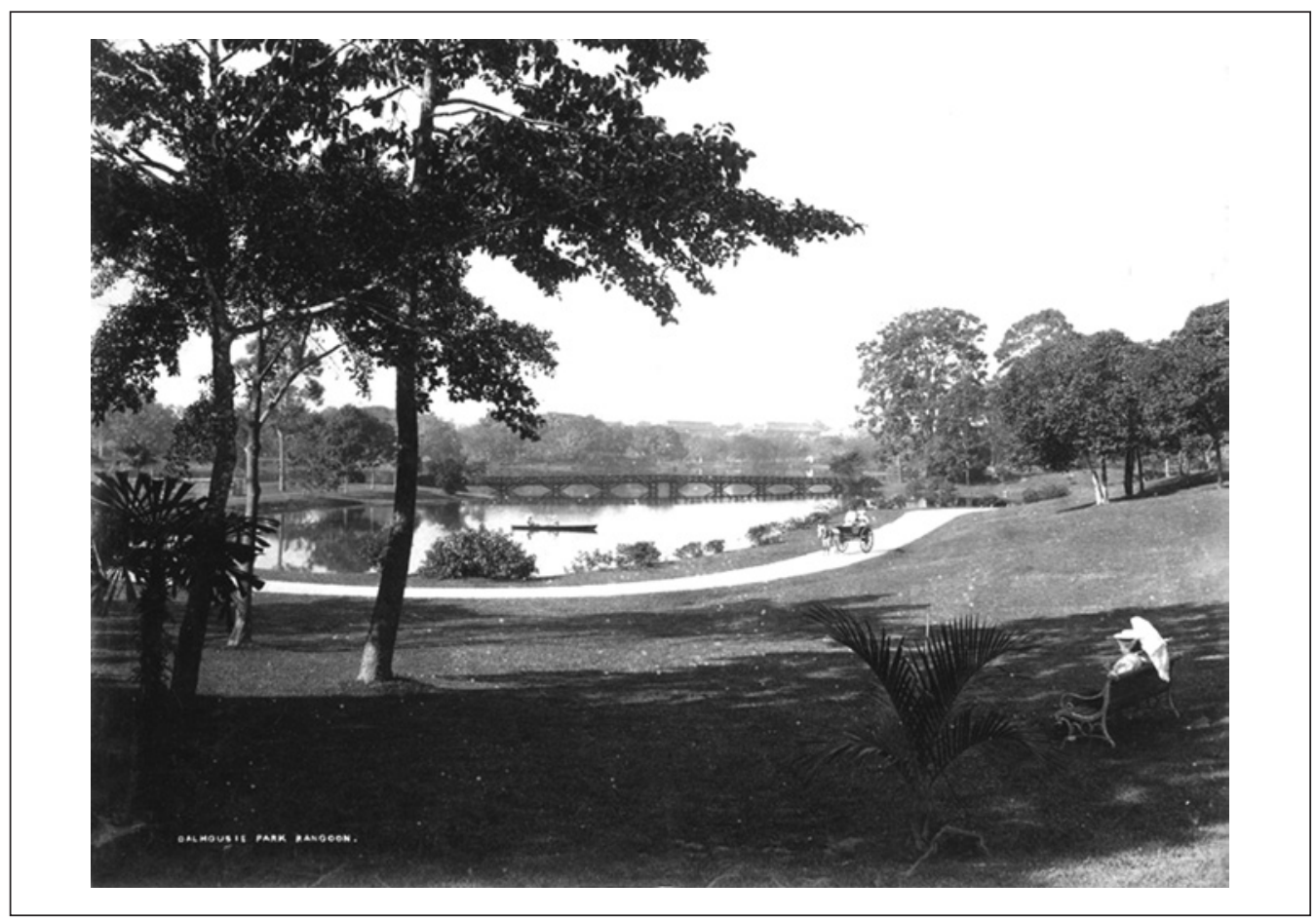

Figure II. Kandawgyi Lake, circa 1900.

Source: Photograph by P. A. Klier (courtesy A. Birnbaum).

\section{British Picturesque Gardens}

This spatial exclusivity also typified the British residential and recreational areas of Rangoon. Because of the international dissemination of picturesque photographs and travel accounts - and the absence of comparable documentation for other groups - it is this perception that is often associated with colonial Rangoon. The images were sold to local residents as postcards to send to relatives at home, as well as through newspapers, magazines, and books on Burma. The photographs shared a common aesthetic that had begun with European landscape and architectural paintings linked to the Grand Tour but then became closely linked to the expanding British Empire. Among many typically romantic images captured by P. A. Klier during his years in Burma (1883-1905) is a photograph of Kandawgyi Lake, one European woman with her parasol on a bench and a single carriage in the distance (Figure 11).

Images such as this produced an "imaginative geography" that encouraged European travel to the colonies, decaying cultures ripe for European civilization. ${ }^{26}$ The most popular icon was the slightly tarnished Shwedagon pagoda, photographed with a few carefully arranged figures giving no sense of the primacy of the pagoda in the civic life of the Burmese. When colonial and local architecture was juxtaposed, the spatial proximity is odd, conveying neither colonial authority nor the intended moldering image of the colony in separating the tangible changes of the city from its civic space. An example can be seen in a circa 1908 photograph by Klier of Ripon Hall on the site where the City Hall was later built: there is little harmony between the imposing massiveness of the hall, a European pergola in the center of the square where evening performances were held and the local religious use of the spaces of the Sule pagoda on the opposite side of the square (Figures 12 and 13). ${ }^{27}$ 


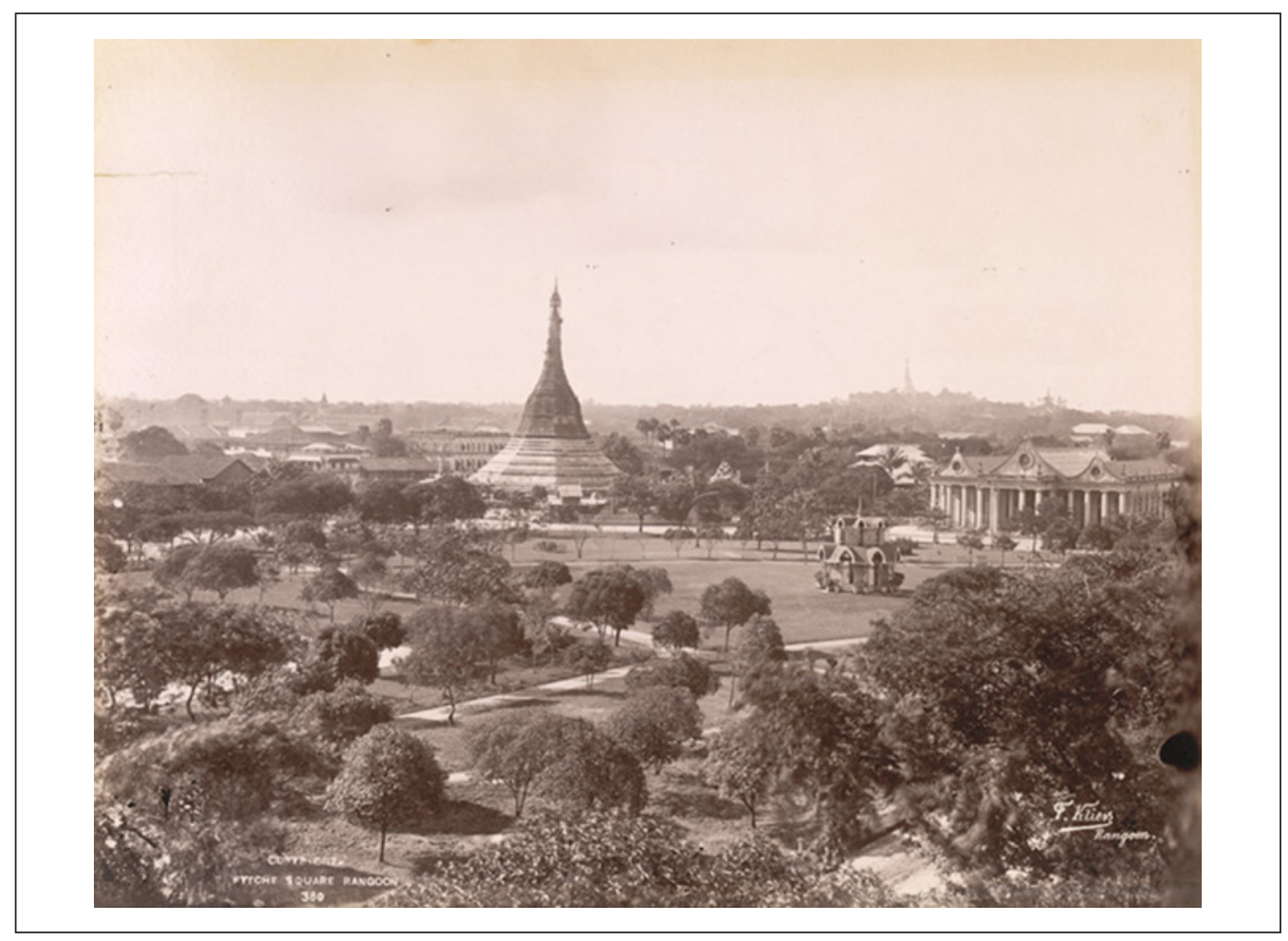

Figure I2. Sule pagoda, 1908.

Source: Photograph by P. A. Klier (courtesy A. Birnbaum).

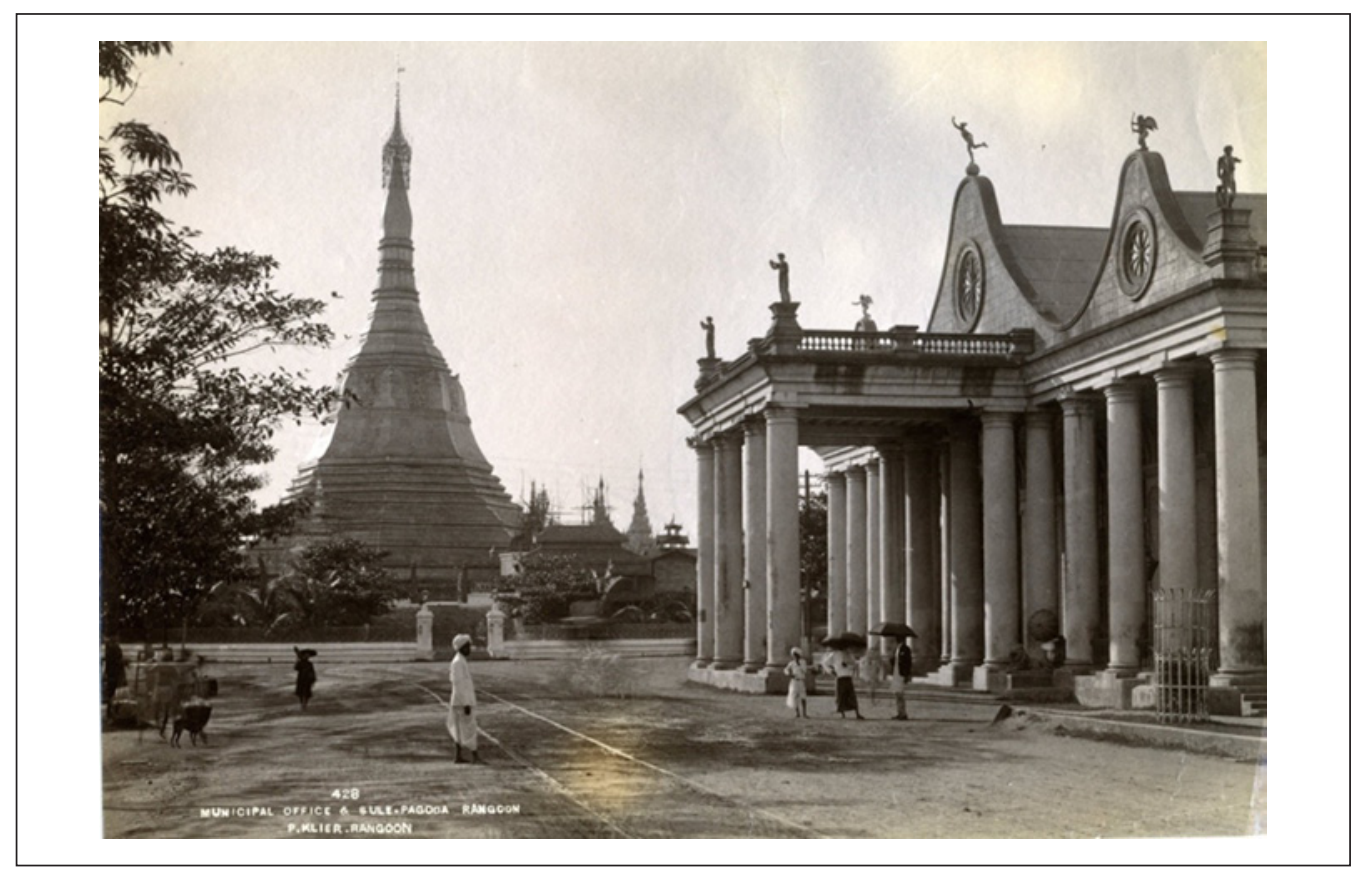

Figure I3. Sule pagoda with pergola in foreground, circa 1895. Source: Photograph by P. A. Klier (courtesy A. Birnbaum). 


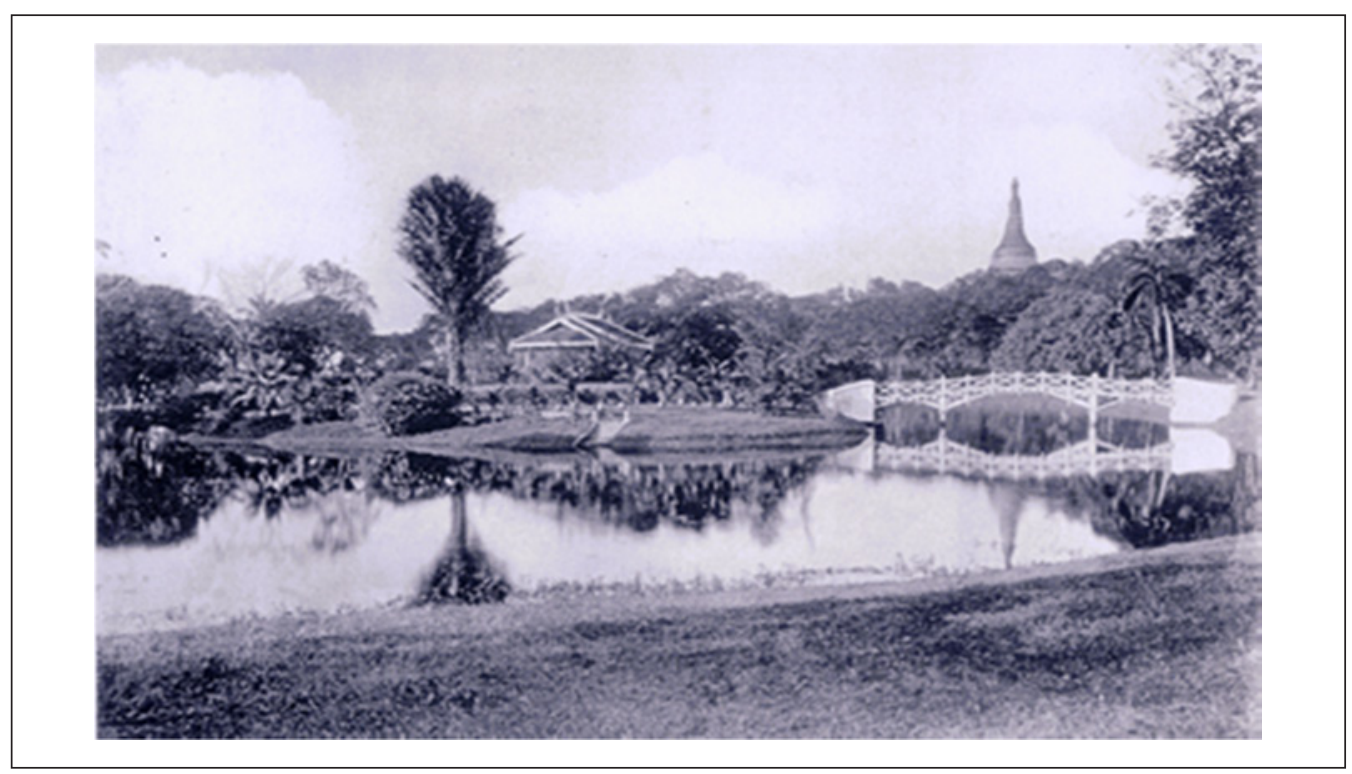

Figure 14. Cantonment Gardens with the Shwedagon pagoda in the distance, circa 1900. Source: Burma: Typical Photographs of Burmese Life and Scenes, Rowe \& Co., Rangoon.

\section{Cantonment and Dalhousie Gardens}

A similar physical dissonance and social distance typified the large British Cantonment, gardens and residential areas, which flanked all but the north side of the Shwedagon throughout much of the late nineteenth and early twentieth centuries. The Cantonment gardens had been established by the Marquess of Dalhousie on his visit to the city in 1854, with a July 12, 1859, report from Captain Harris describing it as a measure to provide goods for European traders, to give troops the means to garden, to make a pleasant place for the soldiers in the Cantonment ... and also "for all classes of the community." 28 The extensive Cantonment in the end included not only the landscaped public gardens but club houses, a parade ground that doubled as a race course and a golf course. Despite the passing mention of "all the classes," not only was the Cantonment space for the British colonial population but was created at the expense of the existing local religious and residential architecture, "[the garden shall be] . . reserved exclusively for Military Residents, Servants, and the approbation of the Commissioner that there should be room to spare ... a great number of pagodas and buildings which can hardly command respect in their present state and which may therefore be used for building purposes without the risk of offense"29 (Figure 14).

The Dalhousie Park area around Kandawgyi Lake on the east of the Shwedagon was also almost exclusively for the foreign community. The park was placed under the Municipal Committee in 1885. After a period of decline, it was refurbished in 1904 under Mr. J. Short, Secretary of the Municipality, becoming "a unique combination of natural beauty and the art of landscape gardening." 30 The north side of the lake, known as Wingaba ("Maze"), had lakeside pavilions and winding byways that made it a favored picnicking spot for the European residents. ${ }^{31}$ Local residents made some use of the gardens but on the south rather than the north side of the lake where the "Wingaba Holy Lake" and the Ngahtatgyi (Wingaba) pagoda were located. ${ }^{32}$

As these details suggest, great attention was paid to the making and maintenance of extensive Cantonment and recreational areas encircling the Shwedagon. However, in the early years of British occupation of Lower Burma (A.D. 1826-1852), numerous pagodas including the Shwedagon were pillaged and monasteries were regularly requisitioned for troops, civil officers, 
and offices as they provided the only "substantial" buildings. ${ }^{33}$ The British sometimes entered, or made efforts to enter into the intellectual world of monasteries but the destruction and occupation severely damaged the vital role of these civic spaces in facilitating the community participation to enliven civic space. ${ }^{34}$ While the British encountered Buddhism as archaeological remains in India, the Buddhist spaces in Rangoon occupied a significant percentage of the new colonial capital. Having little knowledge of the culture they governed and the example of the antiquity of India's Buddhist spaces behind them, pagodas were commonly seen as remains of the past rather than active social spaces in the urban life.

\section{Religious and Civic Space in Rangoon}

North of the downtown grid layout and at the center of the Cantonment and garden areas was the Shwedagon Hill. The traditional processional approach to the pagoda from the river was retained but, from the establishment of British rule in December 1852, the Shwedagon became part of the new province of Pegu. ${ }^{35}$ Provision was made in all the towns of the new Pegu cantonment to regulate local use of pagodas, as noted by I. W. Dalrymple in a letter of June 6, 1854, just "as have been sanctioned for their admission to the Shoe Dagon [sic] at Rangoon." ${ }^{36}$ By December 19,1853 , retention of the "great pagoda" was ordered on "every ground, political and military" for the Shwedagon summit provided a much needed and the best vantage point to control the city. From the time of the first Anglo-Burmese War, access to the Shwedagon was controlled, with an enlargement of an 1824 military map of the "1st Burmese War, Rangoon and Suburbs" showing eight checkpoints including "Nine Pin Picket" along the road from the river to the foot of the pagoda. ${ }^{37}$ Construction on the pagoda platform included housing for troops, bomb proofs, and powder arsenals. The British troops were sensitive to the Shwedagon's beauty but "no Buddha, no rude image of an incarnation, profaned the rites" of a Christian Common Prayer service in the Artillery mess-tent on the platform. ${ }^{38} \mathrm{New}$ gardens were set out as local civic spaces, while the pagodas, the center of community life, were occupied or damaged. Discouragement of local gathering at pagodas can be seen in edicts banning the use of temple maintenance funds for gilding or pagoda festivals. ${ }^{39}$

\section{Conclusion}

The top-down central city planning of nineteenth- to early twentieth-century Bangkok and Rangoon brought new urban forms employing different systems and styles. Siamese kings exercised control to initiate social integration, while British spatial modeling of the city underlined social divisions. The introduction of European forms and priorities in urban designs of early twentieth-century Bangkok and Rangoon brought changes to the vital social traditions that gave meaning to civic spaces. As seen with the contested Shwedagon, the urban populace persisted in maintaining the traditional civic spaces of the temple grounds while the British occupied the platform, created the spacious Cantonment quarters and gardens surrounding it and segregated the bulk of the Indian and Chinese to congested neighborhoods downtown.

In Bangkok, however, royal encouragement personalized an opening of civic spaces in widening the economic and social spectrum of the city. As seen with Wat Benjamabophit and then the winter fairs held in palace and garden grounds, urban forms were designed and employed as a royal forum that incorporated tangible and intangible to create new civic space. It is this disparity in the provision of urban forms in central city planning that underlies our comparison of civic space in nineteenth- to early twentieth-century Bangkok and Rangoon. In Bangkok, as the population and city limits expanded, new civic space was used to implement a royal vision of nationbuilding. King Chulalongkorn and his successor King Vajiravudh actively used the royal persona to implement specific imperial aims in remodeling the city. The monarchs sought out colonial 
examples of administration in Java, Singapore, and Burma and at times hired European architects from these colonial cities but the civic spaces were inspired by Paris, London, and other European capitals. The existing city was rejuvenated, suggesting parity with European imperial modes.

In Rangoon, colonial engineers laid out a new capital and although there were no outright laws, "European and well to do of all races" were allocated broad residential areas surrounded by land designated as open areas. The broad vistas of these parts of the city contrasted with the downtown grid of streets, with main roads paralleling the river and minor ones set across. The cramped lots allocated for business premises where the growing Indian and Chinese population worked and were often housed meant narrow, long premises with windows only at the front and back..$^{40}$ Between 1872 and 1901, as the population expanded, the number of Burmese residents of Rangoon fell. ${ }^{41}$ At the center of the city was the British-occupied Shwedagon, the most important civic space of religious patronage and of political resistance, accommodating not only the occupying British troops but pilgrims, multiethnic donors, festivals, and sharp confrontations with the British. Village pilgrims, elite and royal donors, pwe performers, and police and strikers alternately mingled and clashed in the spaces of the pagoda.

In both cities, urban forms and civic spaces were essential in legitimizing political authority. Imperial forms in Bangkok planning, however, introduced ideas of spatial and social openness whereas colonial development in Yangon reified social disconnection with the Shwedagon civic space the focal point of not only military occupation and community confrontation but continued religious donation and pilgrimage. The sharp contrasts between this fractured significance of civic space and the creation of new forms drawing in past and new uses of civic space in Bangkok demonstrates the manner in which spatial and visual systems colored the production of civic space to initiate social integration in Bangkok and preamble disintegration in colonial Rangoon.

\section{Declaration of Conflicting Interests}

The author(s) declared no potential conflicts of interest with respect to the research, authorship, and/or publication of this article.

\section{Funding}

Research support from the Chulalongkorn University's Research Fund and School of Oriental and African Studies (SOAS), London.

\section{Notes}

1. Bertie Reginald Pearn, A History of Rangoon (Rangoon: American Baptist Mission Press, 1939), 182.

2. Ashok K. Dutt, The Asian City: Processes of Development, Characteristics and Planning (New York: Springer, 1994), 45.

3. Pearn, A History, map 7.

4. See Pearn, A History, 189; and Eric Anderson Walker, The Great Trek (London: A.C. Black, 1934), 220.

5. Heath Schener, Pleasure Gardens, Theme Parks, and the Picturesque (Washington, DC: Dumbarton Oaks, 2002), 85.

6. Thongchai Winichakul, "The Others Within: Travels and Ethno-spatial Differentiation of Siamese Subjects, 1855-1910," in Civility and Savagery: Social Identity in Tai States, ed. Andrew Turton (London: Curzon, 2000).

7. Chris Baker and Phasuk Phongpaichit, A History of Thailand, 2nd ed. (Cambridge University Press, 2005), p. 100.

8. Ross King, Reading Bangkok (Honolulu: Hawaii University Press, 2011), 25-28.

9. Warunee Osatharom, "King Chulalongkorn Visiting British-India in 1872," in King Chulalongkorn: Siam-Southeast Asia-Jambudvipa (Bangkok: Toyota Thailand Foundation, 2004), 280-374 (in Thai).

10. National Archives of Thailand (NA). Records of the Fifth Reign (RV), Ministry of Public Works (Krasuang Yothathikan), Repair and Construction Works, 8/20. 
11. Prince Chulachakrabongse, Chao Cheewit: Siam gon yook prachatippatai (Lords of Life: Siam before democracy), (Bangkok: River Books, 1993), p. 211.

12. Steen Eiler Rasmussen, London: The Unique City (Cambridge: The MIT Press, 1934), p. 95.

13. Monthon Thesaphiban was a centralized administrative system adopted from British India by Prince Damrong Rajanubhab, a Ministry of Interior in 1899 (NA, RV, Plants and Planting Manual 8.1).

14. In 1872, King Chulalongkorn went to Calcutta, Delhi, and Bombay. He visited the Shwedagon but kept his shoes on when entering on to the pagoda platform. This incident not only caused abundant protest from the citizenry of Rangoon but is emblematic of his focus on European imperial models, as the aim of his trip was not interaction with the Burmese monarch but the British colonial authorities. This is seen again one year later during the 1874 Front Palace Crisis, a power struggle between the king and his Viceroy, Prince Bowonwichaichan, which resulted in the Viceroy taking refuge at the British Consulate. In the end, the Viceroy was stripped of his power, but the relatively greater importance of Siam's relations to British Burma rather than the royal court in Mandalay is obvious. In 1919, when an official Resolution was issued by the British government in relation to a case put forward by the Young Men's Buddhist Association protesting the wearing of shoes by Europeans when entering pagoda precincts, the abolishment of prohibiting footwear in Buddhist temples by King Mongkut (r. 1851-1868) was cited by the foreign minister of Thailand, Prince Devawongse. See Seekins, Donald M. State and society in modern Rangoon (London; New York: Routledge, 2011), 50.

15. Phraya Srisahathep (Seng Wirayasiri), Chotmaihet Sadet Prapas Europe Rattanakosin Sok 116 (The archives of royal visit to Europe in 1898) (Bangkok: Trade Organization of the Teacher Council of Thailand, 1998), 308, 424.

16. Anake Nawigamune, Radsadon Bantoeng (Civic Entertainments) (Bangkok: Kurusapha, 1999), 169-77.

17. A collection of primary documents of the inauguration of Wat Benchamabophit, vol. 2, (Bangkok: Amarin, 1995), 172 (in Thai).

18. HH Princess Poonpisamai Diskul, "kwam sanook nai wat benchamabophit" (Enjoyment in wat Benchamabophit), in Sarakadee ti na roo (Bangkok: Sermwit Bannakan, 1973), 125-31 (in Thai).

19. Prince Chulachakrabongs, Kerd Wang Parusk (Born in Paruskavan Palace) (Bangkok: River Books, 1997), 122.

20. Fuang Chawalee, Nirat ngan ruedu naowpen pathom ti yai mamee na phra racha utayan saranrom 2465 (Poetry for the Winter Fair at Saranrom Royal Garden in 1922) (Bangkok: Charoensri Publishing House, 1924), 8-20.

21. Osada, Housing, Figures 2 and 6.

22. See Heng Chye Kiang, "Chinese Public Space, A Brief Account," 85, 89; and Merlyna Lim, "Transient Civic Spaces in Jakarta Demopolis," 214, 229, in Globalization, the City, and Civil Society in Pacific Asia: The Social Production of Civic Spaces, ed. Mike Douglass, K. C. Ho, and Giok Ling Ooi (New York: Routledge, 2007); and Myanmar Heritage Trust, Historical Walks in Yangon (Chiang Mai: Silkworm Books, 2008).

23. Personal communication, Alfred Birnbaum, 2011.

24. Pearn, A History, 195.

25. Donald M. Stadtner, Sacred Sites of Burma: Myth and Folklore in an Evolving Spiritual Realm (Bangkok: River Books, 2011), 59-60; Chen Yi Sein, "The Chinese in Rangoon during the 18th and 19th Centuries," in Essays Offered to G.H. Luce by His Colleagues and Friends in Honour of His Seventy-Fifth Birthday, ed. Ba Shin, J. Boisselier, and A. B. Griswold (Artibus Asiae, 1966), 1/10711; Yin Yin Myint, "Les Chinois de Birmanie," in Etudes birmanies en homage a Denise Bernot, ed. Pierre Pichard and Francois Robinne (Paris: Ecole Francaise d'Extreme Orient, 1998), 261-67.

26. See Henry Neville Hutchinson, John Walter Gregory, and Richard Lydekker, The Living Races of Mankind: A Popular Illustrated Account of the Customs, Habits, Pursuits, Feasts and Ceremonies of the Races of Mankind throughout the World, Vol. 1 with 3999 illustrations (London: Hutchinson, 1901); and Hong Suen Wong, "Picturing Burma: Felice Beato's Photographs of Burma 1886-1905," History of Photography 32, no. 1, (2008): 1-26.

27. Pearn, A History, 285.

28. National Archives of Myanmar document, "Cantonment Gardens at Rangoon" (Yangon: National Archives, Ministry of National Planning and Economic Development, 1859), Ac. No. IAO-480, series 1/1(A), file 82. 
29. Ibid.

30. Pearn, A History, 285.

31. Myanmar Heritage Trust, Historical Walks.

32. Ngahtatgyi Pagoda Trustees, Ngahtatgyi Pagoda History (Nga-htat-gyi-myat-swa-hypaya-thamaing) (Yangon: Hanthawaddy, 2010), 29, 51.

33. Pearn, A History, 195.

34. Alicia Turner, "Buddhism, Colonialism and the Boundaries of Religion: Theravada Buddhism in Burma 1885-1920" (PhD diss., The University of Chicago, 2009), 150.

35. Thant Myint-U, The Making of Modern Burma (Cambridge: Cambridge University Press, 2001), 23.

36. National Archives of Myanmar document, "Cantonment Gardens at Rangoon," 1859.

37. Peter Leicester, The Geology and Underground Water of Rangoon (with special reference to TubeWells) (Rangoon: the Geological Survey of Burma, 1959), plate IX.

38. Laurie, The second Burmese war, 117-118,121, 141.

39. See Penny Edwards, "Relocating the Interlocutors: Taw Sein Ko (1864-1930) and the Itinerancy of Knowledge in British Burma," South East Asia Research 12 (2004): 324-25; and Taw Sein Ko, Report of the Superintendent of the Archaeological Survey for the Year Ending 1902 to 1903 (Rangoon: Government Publishing, 1903).

40. Pearn, A History, Map 7.

41. See Ma Thanegi, Myanmar Architecture: Cities of Gold (Singapore: Times Editions-Marshall Cavendish, 2005); and Noriyuki Osada, "Housing the Rangoon Poor in Colonial Burma." Paper presented at "Sites of Modernity" Workshop, Department of History, Indians, Burmese, and Town Planning, Chulalongkorn University, July 21-22, 2011.

\section{Author Biographies}

Elizabeth Howard Moore, Professor of the Art and Archaeology of South East Asia, Department of History of Art and Archaeology, School of Oriental and African Studies, London, focuses on the Myanmar sacred landscape.

Navanath Osiri, Associate Professor and Head, Department of Landscape Architecture, Chulalongkorn University, Bangkok, focuses on garden design and vernacular adaptations in Southeast Asia. 